was not on the Saskatchewan checklist."

While I had been working on the Canvasbacks, I could see that Dot had stopped and was giving some particular bird an extra-long study. I also saw her running and was disturbed because the Canvasbacks were going into flight. I finished the count and had about 185 Canvasibacks and 20 Redheads. Meanwhile, the plover which had flown in from across the lake had attracted my attention and as it moved leisurely along the shore, passing to within 40 feet, I was able to study all of its field markings. When Dot came within shouting distance, I yelled: "There's a strangelooking plover down the beach about one hundred yards! Where is Peterson's?" Dot told me she thought it was a Snowy Plover and we should phone or try to contact some of the birders in Regina for confirmation. After referring to Peterson's, I agreed with her that here was a Snowy Plover and at once we set out to find a phone.

Before long we had alerted a number of birders and had left word for Bob Nero to try to get to Buck Lake, hoping to obtain the backing of several observers and possibly even a specimen. We returned to Regina at 5:00 p.m., and an hour later picked up Mrs. Ruth Tempel and drove back to Buck Lake. Ruth and Dot started around the lake and before long, almost at the original place, they spotited the Snowy Plover. The wind had shifted to the east and the lake was choppy. At about this time, Elmer Fox drove up with his family, Mrs. Fox, Reg and Doug. Fortunately for science, Elmer possessed a collecting permit and a suitable gun. I directed Elmer and his son, Reg, around the south end of the lake, pointing out about where I thought Ruth Tempel and Dot had the plover located. In a half hour and after much extremely fine stalking, the Foxes flushed the plover and Elmer brought it down with one well-aimed shot, thus positively establishing the occurrence of this species so far from its usual haunts.

Within a few minutes after this tense drama, other observers arrived, including Dr. and Mrs. George Ledingham, Bob Nero, Robert R. Taylor and Miss Carla Stein. Soon we all had a close look at the Snowy Plover. Though there were some who were sorry the bird had to be collected, all agreed that cbtaining the specimen was scientifically desirable.

\section{LITERATURE CITED}

American Ornithologists' Union. 1957. Checklist of North American birds. Fifth ed. 691 pp.

Bent, A. C. 1929. Life histories of North American shore birds (Part 2). Nat'l. Mus. Bull. 146, $412 \mathrm{pp}$.

Peterson, R. T. 1961. A field guide to western birds. Houghton-Mifflin Co. 366 pp.

\title{
First Specimen Record of Pine Warbler for Saskatchewan
}

by Margaret Belcher and Robert W. Nero, Regina

A "million dollar" rain, welcomed by farmers across the prairies after a dry spring, began to fall in Regina on Saturday evening, May 2, 1964. Two days of heavy showers followed, and already by. Sunday, May 3, waves of migrant sparrows, thrusihes and warblers were "grounded" in the city. Large flocks of Myrtle Warblers were watched in the rain on Sunday and Monday, flying down from the branches of the leafless trees to feed on the lawns and roadways in the Legislative grounds. With the Myrtles on Sunday, May 3, were small numbers of Orange-crowned Warblers, several Black-and-white Warblers and a Blackpoll Warbler, and the first of the season's Northern Waterthrush. Then on Monday, May 4, Palm Warblers were noted, and a first Yellow Warbler (the earliest recorded spring arrival for the Regina area). Naturally, Regina birders spent considerable time in the Legislative Grounds observing this unusual concentration of warblers, and on Tuesday and Wednesday we were still taking sandwiches to eat in the park so that we could watch them at the noon hour.

The early arrival of several of the warblers-Yellow Warbler on May 4, and Ovenibird on May 6, was an in- 
teresting feature of the migration, but its highlight was certainly the first established record for Regina of the Pine Warbler Dendroica pinus (Wilson). The details of the sighting were recorded that day in Belcher's notes, from which we quote the following: "At noon on May 6 four of us from the Regina Campus, Lucy Murray, Amalia Pucat, Alvin Fcrd and myself, were checking warblers, sparrows, thrushes and empidonax flycatchers on the treed lawns north of the Legislative Buildings. A warbler flew in front of me, showing white in its tail and greenish-yellow head and back. Thinking it a Palm Warbler, I was surprised to see when it lit on the lawn that it had no chestnut cap, and a minute later when it flew into a tree, further distinguishing marks were evident-wing bars, yellow breast, greyish-white on lower abdomen and undertail coverts, and greyish legs. I called the others, and Lucy Murray and I were both able to get good views with our binoculars before I went back to the car for Peterson's Field Guide to the birds to help identify it. When the bird was seen to resemble Peterson's picture of the Pine Warbler, a species still listed as hypothetical on the Field check-list of Saskatchewan birds (4th ed., 1959), I hurried back to the Campus to bring Dr. Robert Nero. Fortunately the bird was still in the area when we returned and we soon located it again, flitting from tree to tree and perching briefly on an outer branch before it flew into the air for insects. Dr. Nero was therefore able to collect the bird, the first specimen record for Saskatchewan."

Judging by its plumage the specimen appears to be a female; unfortunately, no sign of gonads could be found-the absence of testes suggests that it was a female and the ovary may have been destroyed by shot which had hit the left side heavily. The remiges and rectrices are rather worn. It was carrying a medium amount of fat. It is preserved as a study skin at the Regina Campus. The taking of the specimen establishes definitely the occurrence of the Pine Warbler in Saskatchewan where it has been suspected for many years. In fact the A.O.U. Checklist (1957) reports the subspecies Dendroica pinus pinus (Wilson) as casual in southern Saskatchewan (Wingard, Indian Head), as well as in eastern Alberta (Rochester, Castor) and North Dakota (Arnegard, Jamestown, Fargo). However, Houston and Street (1959) believed that the Wingard report, which originated with John Alden Loring, an employee of the U.S. Biological Survey who visited Wingard from July 13-31, 1895, and reported the Pine Warbler as common along the river, "must represent an error in identification, for this species cculd not have been 'common'." Could they have been more common in the past?

The reference in the A.O.U. Checklist to Indian Head is apparently based on the records of George Lang. "Three were seen on May 21, 1929, at Indian Head by Geo. H. Lang; the species was seen again by Lang the following day. Lang stated that they were 'moderately common. Does not breed"." (Houston, 1958:45-46). These records are from Lang's migration list of 1929; Lang kept records for many years, but unfortunately, most of his records have been lost and it it not known whether or not he had other records of this species (Manley Callin, pers. commun.).

The files of the Saskatchewan Museum of Natural History have an informal record left in the form of a note by $N$. Albulet to the effect that L. B. Potter "saw one 2 weeks ago (May 20, 1937) at Eastend."

In the Regina area, too, a number of sight records have been reported through the years. J. H. Taylor's notes (1931-1943) have occasional references to the Pine Warbler, chiefly in spring migration, as observed by himself and/or other members of a small group of enthusiastic birders who "covered" the spring migration by going out on 6:00 a.m. morning bird hikes (May 23, 1935; May 5, 1936; May 24, 1936; May 25, 1937; Sept. 6, 1937; May 28, 1939). An observation during the fall migration, August 29, 1961, was recorded in some detail in Frank Brazier's notes, with a sketch made in the field to show characteristic markings and colour. Last year (1963) a sighting was reported from the farm of the Provincial Correctional Institution near Regina by Al Binnie who 
reported one "viewed at close range with binoculars", May 19.

Migrant warblers of this rather inconspicuous type are less easily identified than many showy birds, and the possibility of confusing them with other species, especially in fall plumage, makes it difficult to be certain about the identification of a rare species. In these cases, a specimen record becomes especially important, and adds significance to the previously recorded sight records. It should especially be noted that the specimen had greyish legs, not black as given by Peterson (1947).

According to the A.O.U. Check-list (1957), the Pine Warbler is known to breed in southern Manitoba (Winnipeg, Indian Bay). Salt and Wilk (1958:384) report for Alberta as follows: "The only specimen of the pine warbler taken in Alberta is a male collected at Castor in June, 1924. During the summer of 1928 several pairs of pine warblers were observed near the town of Athabasca. They appeared to have established territories but no direct evidence of nesting was found. There are also sight records of pine warblers at Glenevis and in the Cypress Hills." Could it breed in Saskatchewan? Griscom (Griscom and Sprunt, 1957: 176-177) reports that this species, which is especially adapted to various species of pine trees chiefly in the eastern United States, has been steadily decreasing as a result of clearing of pine forests outside the coastal plain. "Its effort to push north and establish itself in other types of pine woods has not been conspicuously successful." However, L. H. Walkinshaw (in Griscom and Sprunt, loc. cit.) notes for Michigan that the Pine Warbler is found in jack pine, which is the predominant tree throughout the northern portion of the lower peninsula, seeming to prefer stands where the trees are over 25 feet in height. In view of the resemblance of its song to that of the Chipping Sparrow it may well be that we have overlooked a species which may be resident in some parts of Saskatchewan.

\section{LITERATURE CITED}

American Ornithologists' Union. 1957. Checklist of North American birds. 5th edition. Baltimore. $691 \mathrm{pp}$.

Houston, S. 1958. An evaluation of the distribution records for Saskatchewan birds in the revised edition of the A.O.U. Checklist. Blue Jay, 16:44-47.

Houston, C. S., and M. G. Street. 1959. The birds of the Saskatchewan River, Carlton to Cumberland. Sask. Nat. Hist. Soc. Spec. Pub. No. 2, Regina. 205 pp.

Solt, W. R., and A. L. Wilk. 1958. The birds of Alberta. The Queen's Printer, Edmonton. $511 \mathrm{pp}$.

Griscom, L., and A. Sprunt, Jr. 1957. The warblers of North America. Devin-Adair Co., New York. 356 pp.

Peterson, R. T. 1947. A field guide to the birds. Houghton Mifflin Co., Boston. 290 pp.

\section{Brewer's Sparrow at Regina}

\section{by Robert W. Nero, Regina}

Strong southwest winds brought a large wave of migrant sparrows to the Regina district in mid-May, reaching peak numbers for Chipping Sparrows (Spizella passerina), and especially Clay-colored Sparrows (Spizella pallida), on the 16th of May, the day of the Regina Annual May Count. At noon on that day, Frank H. Brazier and I stopped for lunch in a small grove of trees surrounding abandoned farm buildings about a quarter of a mile southwest of Condie, a station about six miles northwest of Regina. It was a warm day with a dry wind that led us to seek shade. A large number of Claycolored Sparrows evidently felt the same way, for their buzzy calls were conspicuous in the little grove. As we sat down for lunch we heard two or three melodious notes of an unfamiliar species; we decided that whatever the species, it would likely remain in the grove for the lunch period. About 30 minutes later we searched through the trees and hedge but were unable to find any bird to which we could attribute the melodious notes; however, a short while later, upon sounding the auto horn, I was surprised to hear a song which included the notes we had heard earlier. It seemed to have responded to the horn and a moment later when I made a "shhh-shhh" sound, which I had been using to lure birds into sight, it sang again, quite close at hand and close to the base of some balsam poplar trees. I had a glimpse 